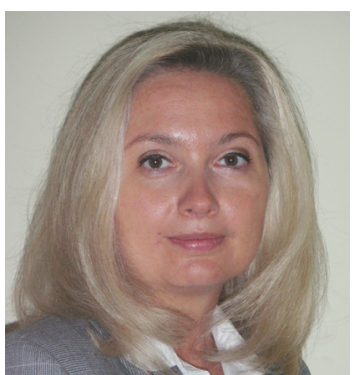

Magdalena Lewicka

Magdalena Lewicka - doktor nauk humanistycznych, kierownik Pracowni Języka i Kultury Arabskiej UMK; arabistka i islamoznawca, lektorka języka arabskiego, tłumaczka przysięgła; absolwentka arabistyki i islamistyki na Wydziale Orientalistycznym Uniwersytetu Warszawskiego, Zarządzania i Administracji w Instytucie Handlowym na Uniwersytecie w Damaszku oraz Szkoły Języka Arabskiego dla Obcokrajowców w Damaszku i Kairze. Prowadzi badania naukowe w zakresie arabistyki i islamistyki oraz glottodydaktyki. Autorka licznych publikacji naukowych i popularnonaukowych, współredaktorka monograficznych prac zbiorowych: Dialog chrześcijańsko-muzułmański. Historia i współczesność, zagrożenia i wyzwania (2011), Dialog chrześcijańsko-muzułmański. Klucz do wspólnej przyszłości (2012), Dialog chrześcijańsko-muzułmański. Teoria - praktyka - perspektywy (2013), Dydaktyka języka arabskiego. Teoria - praktyka - perspektywy (2013). 


\section{Europa w arabskiej myśli społeczno-politycznej XIX wieku}

DOI: http://dx.doi.org/10.12775/LC.2014.006

\section{W kierunku odnowy - myśl spoleczno-polityczna okresu An-Nahdy}

adając genezę i rozwój myśli reformatorskiej w świecie arabsko-muzułmańskim, zauważamy dwa mechanizmy, które doprowadziły do ukształtowania się tejże myśli. Z jednej strony tendencje modernistyczne, które były wynikiem upadku i zastoju, implikujących dążenia do odnowy i naprawy istniejącego stanu, a więc potrzeba reform wyrosła na gruncie przekonania o potrzebie zmian wobec świadomości niedoskonałości i chęci odzyskania minionej świetności, co doprowadziło do wykrystalizowania się ruchu określanego terminem islah - naprawa, dążącego do tadżdid - odnowy. Twórcy takich ruchów to Muhammad Ibn Abd al-Wahhab, Wali Allah, Muhammad Ibn Abd Allah asz-Szawkani i inni. Z drugiej zaś strony - ideologie reformatorskie będące $\mathrm{w}$ dużym stopniu pochodną kontaktów z cywilizacją europejską, rodzące się pod wpływem Zachodu, a przede wszystkim rozczarowania jego pozorną nowoczesnością cywilizacyjną, podzielone na dwa nurty - modernistyczny, z którego wyrosły nacjonalizmy lokalne i tendencje sekularystyczne oraz konserwatywny, nazywany klasycystycznym, który dał początek fundamentalizmowi ${ }^{1}$. Przedstawiciele tych nurtów to: Dżamal ad-Din al-Afghani, Muhammad Abduh, Abd ar-Rahman al-Kawakibi, Muhammad Raszid Rida, Ahmad Khan, Muhammad Ikbal, a także Chajr ad-Din at-Tunusi i Rifa at-Tahtawi.

1 Fundamentalizm muzułmański - zob.: J. Danecki, Podstawowe wiadomości o islamie, Warszawa 2007, s. 481-508; H. A. Jamsheer, Historia powstania islamu jako doktryny społeczno-politycznej, Warszawa 2009, s. 179-192; idem, Reforma władzy i społeczeństwa w arabsko-muzułmańskiej myśli politycznej wieków XIX i XX, Łódź 2008, s. 124-138. Zagadnienie fundamentalizmu religijnego omawia w polskim piśmiennictwie m.in. K. Armstrong, W imię Boga. Fundamentalizm w judaizmie, chrześcijaństwie i islamie, Warszawa 2005; B. Tibi, Fundamentalizm religijny, Warszawa 2001; S. Bruce, Fundamentalizm, Warszawa 2006. 
Ich koncepcje reformatorskie pojawiły się w wieku XIX, a więc okresie szczególnym $\mathrm{w}$ historii społeczeństw, z jego cechą charakterystyczną w postaci nowych idei, u podstaw których legła Rewolucja Francuska i wielka rewolucja przemysłowa, a które wywarły ogromny wpływ na życie ówczesnej Europy i odbiły się szerokim echem na pozostałych kontynentach. Zainicjowały epokę przemian, nie tylko w zakresie działalności politycznej i gospodarczej, lecz także społecznej, której istotnym elementem była coraz większa świadomość praw i obowiązków, przemian, których punktem wyjścia była Europa, obdarzona pozycją dominującą na mapie świata, tak pod względem ekonomicznym, jak i ideologicznym.

Początki wpływów Zachodu na świat islamu sięgają przełomu XVIII i XIX wieku, kiedy Anglicy znaleźli się w Indiach i na Bliskim Wschodzie, Francuzi w Afryce Północnej, a Rosjanie w Azji Środkowej i na Kaukazie, a znacznie wcześniej, bo już w wieku XVII, Portugalczycy osłabili potęgę Turcji Osmańskiej, odbierając jej monopol na Oceanie Indyjskim i przekraczając Zatokę Perską. Na przełomie XVIII i XIX wieku ekspansja przemysłowej Europy na Bliskim Wschodzie zaznaczyła się szczególnie silnie, a za główne wydarzenie, które wpłynęło na ówczesny świat arabski uważa się wyprawę Napoleona na Egipt w 1798 roku. Wówczas bowiem społeczeństwo muzułmańskie zostało zmuszone do przyjęcia europejskich osiągnięć z jednej strony i do wyrażenia własnej tożsamości wobec obcych wpływów z drugiej. W tym okresie pojawiły się takie ideologie, jak panarabizm i panislamizm, dwa najważniejsze nurty w muzułmańskiej myśli XIX i XX stulecia, których siłą przewodnią był najpierw zachwyt, potem rozczarowanie Zachodem, ale też doświadczenia europejskiego kolonializmu, którego ślady są nadal trwałe w świecie arabskim.

Na podłożu konfrontacji z ekspansją technologiczną, gospodarczą i ideologiczną Europy wyrastają reformy sułtanów Mahmuda $\mathrm{II}^{2}$ i Abd al-Madżida I ${ }^{3}$ w Imperium Osmańskim oraz „wicekróla” Egiptu, Muhammada Alego ${ }^{4}$, pod którego panowaniem państwo to zaczęło odgrywać rolę głównej siły arabskiego odrodzenia cywilizacyjnego, określanego mianem An-Nahda (Odrodzenie) $)^{5}$. Pojawiają się koncepcje reformatorskie, szukające mechanizmów wyjścia z problemów, jakie niosła za sobą potęga i wielkość Zachodu, nowoczesne nauki i technologie, polityczne instytucje państwowe, socjalna moralność nowoczesnych społeczeństw. Starały się dać odpowiedź na fundamentalne pytanie o to, w jaki sposób cywilizacja arabsko-muzułmańska może się umocnić, by stawić czoło europejskiej i stać się częścią nowoczesnego świata.

2 Mahmud II (1785-1839) - sułtan turecki w latach 1808-1839, przeprowadził reformy w zakresie ustanowienia zasad sprawowania władzy, zreorganizował armię na wzór europejski, rozwiązał korpus janczarów w $1826 r$.

3 Abd al-Madżid (1823-1861) - sułtan turecki w latach 1839-1861. Zapoczątkował tanzimat („porządkowanie") edyktem Hatt-i szerif z 1839 r., który umożliwił utworzenie rady legislacyjnej, ministerstwo spraw zagranicznych, wewnętrznych i handlu, a na podstawie kolejnego edyktu, Hatt-i Hümayun z 1856 roku, zreformował system administracji prowincji i system podatkowy. W 1850 r. wprowadził pierwszy kodeks handlowy, w 1869 r. zainicjował prace nad kodeksem postępowania cywilnego.

${ }^{4}$ Muhammad Ali (1769-1849) - „wicekról” Egiptu w latach 1805-1848 oraz 1848-1849, nazywany przez historyków twórcą potęgi tego kraju. Dzięki centralizacji władzy przeprowadził reformę rolną, administracyjną i edukacyjną, oparte na wzorcach europejskich. W literaturze polskiej działalność Muhammada Alego omawia praca B. Stępniewskiej-Holzer, Muhammad Ali, Wrocław 1978.

${ }^{5}$ Czasy odrodzenia arabskiego oraz tło społeczne i umysłowe epoki przedstawiają m.in.: A. Hourani, Arabic Thought in the Liberal Age 1798-1939, Cambridge 1998, przekład arabski: Al-Fikr al-arabi fi asr An-Nahda 1798-1939, przekład K. Azkul, Bajrut 1977; M. Ibn Aszur, Al-Haraka al-adabijja wa-al-fikrijja fi Tunis, Al-Kahira 1956; M. Musa, Al-Fikr al-arabi fi al-asr al-hadis, Bejrut 1973; M. Musa, Al-Fikr as-sijasi al-arabifi al-asr al-hadis, Tarabulus (Liban) 1995; M. Al-Kadi, A. Sula, Al-Fikr al-islahi inda al-Arab fi asr An-Nahda, Tunus 1992; H. Szarabi, Al-Mutatakkafun al-'Arab wa-al-gharb, Bejrut 1978; B. As-Siba'i, Al-Fikr al-idżtima'i wa-as-sijasi al-hadis, Bajrut 1978. 
Moderniści przekonywali, że islam jest zdolny do przetrwania w obliczu potęgi i postępu ówczesnej rzeczywistości, że nie tylko można go pogodzić z rozumem, postępem i solidarnością społeczną, a więc podstawami współczesnej cywilizacji, lecz nawet więcej - że w jego naukach można odnaleźć korzenie owych wartości. Takie poglądy reprezentował Dżamal ad-Din al-Afghani, twórca idei panmuzułmańskiej, postulujący syntezę zreformowanych i zmodernizowanych wartości kultury islamu $\mathrm{z}$ wartościami zapożyczonymi z Zachodu, w przekonaniu, że możliwe jest dostosowanie islamu do potrzeb nowoczesnego świata. Jego koncepcje rozwinął w praktyce jeden z jego uczniów i współpracowników, Egipcjanin Muhammad Abduh - prekursor panarabizmu, a kontynuowali je inni przedstawiciele świata arabsko-muzułmańskiego.

\section{Chajr ad-Din at-Tunusi i Rifa at-Tahtawi - prekursorzy europejskiego modernizmu}

Myśl reformatorska Chajr ad-Dina at-Tunusiego i Rifa'y at-Tahtawiego zrodziła się w XIX wieku, naznaczonym konfrontacją pomiędzy rozwiniętym i uzyskującym coraz większe wpływy Zachodem a pogrążonym w zastoju, ulegającym potędze Europy światem arabsko-muzułmańskim ${ }^{6}$. Konieczność owej konfrontacji i głęboka świadomość bezsilności społeczności muzułmańskiej wobec dominacji zachodniej legły u podstaw każdej późniejszej arabskiej myśli politycznej i stały się siłą motoryczną poszukiwania drogi wiodącej do odzyskania dawnej potęgi i siły, które od zarania dziejów odgrywały rolę szczególną w światopoglądzie muzułmańskim. Takiej drogi poszukiwali At-Tunusi ${ }^{7}$ i At-Tahtawi ${ }^{8}$, reformatorzy, którzy - podobnie jak inni przedstawiciele XIX-wiecznego odrodzenia arabskiego ${ }^{9}$

${ }^{6}$ Na temat historii świata arabskiego zob.: J. Danecki, Arabowie, Warszawa 2001; M. Gdański, Arabski Wschód: Historia - gospodarka - polityka, Warszawa 1963; U. Haarmann (red.), Geschichte der arabischen Welt, Monachium 2001; Ph. Hitti, Dzieje Arabów, tłum. W. Dembski, M. Skuratowicz, E. Szymański, Warszawa 1969; A. Hourani, Historia Arabów, tłum. J. Danecki, Gdańsk 2002; B. Lewis, Arabowie w historii, tłum. J. Danecki, Warszawa 1995; B. Lewis, Bliski Wschód, tłum. K. Mierzęcki, Warszawa 1998; B. Lewis, Islam in History. Ideas, People and Events in the Middle East, London 1973; B. Lewis, Muzułmański Bliski Wschód, tłum. J. Danecki, Gdańsk 2003; D. Madeyska, Historia świata arabskiego. Okres osmański 1516-1920, Warszawa 1988; J. Zdanowski, Historia Arabii Wschodniej, Wrocław 2008; idem, Historia Bliskiego wschodu w XX wieku, Wrocław 2010.

7 Życie i działalność reformatora omawiają szczegółowo dwie monografie w języku francuskim: G. S. Krieken, Khayr al-Din et la Tunisie (1850-1881), Leiden 1976 i M. Smida, Khereddine ministre reformateur, Tunus 1970 oraz opracowania arabskojęzyczne - S. Abu Hamdan, Chajr ad-Din at-Tunusi, Bejrut 1993; A. Al-Husi Chajr ad-Din at-Tunusi - abu An-Nahda, Tunis 2004; M. Mazali, Chajr ad-Din radżul ad-daula, Tunus 1971; M. AszSzamli, Chajr ad-Din Basza, Tunus 1973.

8 Wokół życia i działalności reformatora zob.: I. Altman, The Political Thought od Rifa'ah Rafi at-Tahtawi, a Nineteenth Century Egiptian Reformer, Los Angeles 1976, S. Abu Hamdan., Rifa at-Tahtawi: Ra'id at-tahdis al-urubi fi Misr, Bajrut 1992; S. Abu Hamdan, Rifa at-Tahtawi: Ra'id at-tanwir fi al-asr al-hadis, Al-Kahira 1984; M. Amara, Al-A'mal al-kamila li-Rifa at-Tahtawi, Bejrut 1973; H. F. An-Nadżdżar, Rifa at-Tahtawi: Ra'id fikr waimam nahda, Al-Kahira [brak daty wydania], Dż. Asz-Szajjal, Rifa Rafi at-Tahtawi, Al-Kahira 1970.

9 Na temat głównych przedstawicieli arabskiego odrodzenia zob.: S. Abu Hamdan, Mawsu'at asr AnNahda, t. I-X, Bajrut 1992-1994; A. Amin, Zu'ama al-islah fi al-asr al-hadis, Al-Kahira 1965; J. Danecki, Podstawowe wiadomości o islamie, Warszawa 2007; K. S. Al-Husry, Three Reformers, Bajrut 1966; H. A. Jamsheer, Historia powstania islamu jako doktryny społeczno-politycznej, Warszawa 2009; H. A. Jamsheer, Reforma władzy i spo- 
- głęboko przeżywali ówczesną sytuację swoich ojczyzn i całego świata islamu, dlatego skierowali zainteresowania ku analizie przyczyn zacofania i mechanizmów prowadzących do ponownego rozwoju cywilizacyjnego tego świata i przywrócenia należnego mu miejsca na arenie międzynarodowej. Przekonani o tym, że rozwój i bogactwo Europy nie biorą początku w systemie filozoficzno-religijnym, lecz wyłącznie w wiedzy i racjonalizmie, postulowali z jednej strony korzystanie z nich celem podniesienia świata arabsko-muzułmańskiego z upadku i kryzysu, z drugiej zaś - znalezienie ich źródła w szariacie celem pogodzenia ich $\mathrm{z}$ islamem i muzułmańską tradycyjną teorią polityczną.

Ich myśl reformatorska wpisała się w ciekawy dyskurs, który toczy się w świecie arabsko-muzułmańskim od zarania XIX wieku, dyskurs wokół niezwykle ważnych zagadnień ustrojowych, reform polityczno-społecznych, porównania systemu przedstawicielskiego, demokracji z jego przeciwieństwem, despotyzmem, a także wokół poszukiwania dróg wyjścia ze stagnacji i zacofania, poszukiwania, którego niezbędnym elementem była podkreślana przez wszystkich myślicieli reforma systemu edukacyjnego. Ich celem było udzielenie odpowiedzi na nurtujące przedstawicieli tego świata podstawowe pytanie o przyczynę jego upadku i zacofania oraz podstawy europejskiej supremacji, z uwzględnieniem roli despotycznych rządów, anachronicznych struktur społecznych, braku nowoczesnego systemu szkolnictwa i innych zagadnień, ale przede wszystkim - skrystalizowanie idei i wyobrażeń dotyczących relacji pomiędzy tradycją a nowoczesnością, wspólczesnym systemem państwowym, społecznym i politycznym. Stąd rozważania wokół ułożenia stosunków z Zachodem i charakteru tych relacji, przyjęcia całkowicie lub częściowo europejskich wzorców rządzenia, ustosunkowania do panującego ustroju politycznego oraz konieczności zreformowania go lub przekształcenia, demokracji i autorytaryzmu, zakresu praw obywatelskich oraz podległości obywatela w stosunku do państwa.

At-Tunusi i At-Tahtawi byli jednymi z pierwszych myślicieli arabskich, którzy z ogromną wnikliwością i głęboką świadomością obserwowali nowożytną cywilizację zachodnią ${ }^{10}$, jednak ich poglądy na temat państwa i społeczeństwa nie były prostą refleksją idei poznanych zagranicą ani też powtórzeniem tradycyjnego religijnego światopoglądu, lecz próbą wypracowania kompromisu pomiędzy wzorcami europejskimi a szariatem i osadzenia go $\mathrm{w}$ tradycji muzułmańskiej, celem pogodzenia z islamem i jego teorią polityczną. U podstaw tej metody legła konieczność udowodnienia, że po pierwsze owa europejska wiedza i nauki należały do świata arabsko-muzułmańskiego, zanim przejął je Zachód, a po drugie - nie ma sprzeczności pomiędzy wiarą i nowoczesnością, przeciwnie - rozwój państwa i społeczeństwa należy do religijnych obowiązków władzy, która winna dbać o realizację dobra powszechnego, pomnażanie dóbr i rozwój sfer użyteczności publicznej, panowanie sprawiedliwości oraz eliminowanie niesprawiedliwości i ucisku, zapewnienie swobód obywatelskich, wspieranie działalności gospodarczej i aktywności społecznej.

Tak więc ich podziw dla europejskiej myśli politycznej dotyczącej władzy, społeczeństwa, systemów prawnych, politycznych i społecznych, nie implikował ani rezygnacji z tradycji muzułmańskiej, ani indyferentyzmu wobec niej, przeciwnie - u podstaw owego po-

łeczeństwa w arabsko-muzułmańskiej myśli politycznej wieków XIX i XX, Łódź 2008; A. Asz-Szanufi, Al-Wazir Chajr ad-Din wa-mu'asiruhu, Tunus 1990.

10 Rifa at-Tahtawi przez 5 lat (1826-1831) towarzyszył jako duchowny misji egipskich stypendystów w Paryżu, Chajr ad-Din at-Tunusi odbył szereg podróży do krajów europejskich: 1846 - Francja, 1853-1857 - Francja, 1857 - Anglia, 1859 - Turcja, 1861 - Francja, Szwecja, Prusy, Wielkie Księstwo Baden, Holandia, Belgia, Dania, 1863 - Francja, Austria, Prusy, 1864 - Francja, Włochy, Prusy, Turcja, 1865 - Francja, 1867 - Francja. 
dziwu legło przekonanie, że myśl społeczno-polityczna islamu od zarania dziejów głosiła idee stanowiące trzon europejskiej myśli oświeceniowej. W ten sposób doktryna społeczno-polityczna obu myślicieli oparta została na ideach Wielkiej Rewolucji Francuskiej oraz na zasadzie, że naród powinien korzystać z przywilejów wolności politycznej i osobistej, mechanizmy zaś regulujące relacje pomiędzy władzą a społeczeństwem winny opierać się na poszanowaniu praw. Rządzący i rządzeni (hakim wa-mahkum) stanowią dla myślicieli dwa filary państwa, komplementarne w stosunku do siebie i znajdujące się w stanie wzajemnych interesów, czyli relacji praw i obowiązków jednych względem drugich: „Władza jest jak dusza, a poddani jak ciało, a dla ciała nie ma egzystencji bez duszy”. Rządzeni winni darzyć władzę (daula, mamlaka, hukuma, wali al-amr) zaufaniem w zamian za uzyskane korzyści i ochronę, zachowując jednocześnie prawo do pełnej wolności (kamal al-hurrijja) i korzystania z publicznych korzyści (manafi umuma), tj. bogactw narodowych, które winny być dzielone sprawiedliwie pomiędzy poddanych.

Jako pionierzy odnowy w świecie arabsko-muzułmańskim postulowali koncepcję rozwoju cywilizacyjnego (tamaddun) celem poprawy anachronicznych struktur życia politycznego i społecznego, polepszenia warunków życia, rozwoju edukacyjnego, a co za tym idzie - postępu i dobrobytu. Atrybutami tegoż rozwoju miało być poszanowanie prawa muzułmańskiego (szari'a) oraz przejęcie od Zachodu nauk i sztuk (ulum wa-máarif), a więc pójście jego śladem, co było możliwe tylko dzięki otwarciu się świata muzułmańskiego na zdobycze europejskiej kultury i cywilizacji. To przekonanie stanowiło punkt wyjścia do rozważań nad różnymi aspektami problematyki reformy władzy i społeczeństwa, posłużyło stworzeniu zrębów własnej doktryny w imię dokonania transformacji politycznej, społecznej i kulturalnej mającej na celu rozwój zdolności i potencjału ummy oraz odzyskania należnego światu arabsko-muzułmańskiemu miejsca na arenie międzynarodowej.

Cechą charakterystyczną obu reformatorów jest z całą pewnością połączenie dwóch osobowości: myśliciela i czynnego uczestnika życia społeczno-politycznego dzięki pełnieniu szeregu funkcji publicznych. At-Tunusi szybko pokonywał kolejne szczeble kariery wojskowej (dowódca kawalerii, naczelny dowódca, pułkownik, generał dywizji) i politycznej (minister marynarki, przewodniczący parlamentu oraz premier Tunezji, potem minister stanu, przewodniczący Komisji Gospodarczej i Finansowej i wielki wezyr Imperium Osmańskiego), At-Tahtawi natomiast na polu edukacji, kultury i oświaty (wykładowca Al-Azharu, imam wojska egipskiego i duchowny misji egipskich stypendystów w Paryżu, tłumacz w szkołach specjalistycznych w Kairze, dyrektor Madrasat al-Alsun, redaktor naczelny gazety „Al-Waka’i al-Misrijja”, tłumacz i koordynator przekładów dzieł europejskich na język arabski, autor podręczników, członek kolejnych komisji edukacyjnych i inicjator szeregu instytucji wychowawczo-kulturalnych), co sprawiło, że ich działalność nabrała jedynego $\mathrm{w}$ swoim rodzaju charakteru poprzez realizację $\mathrm{w}$ praktyce idei wypracowanych $\mathrm{w}$ teorii.

Egipski reformator jest autorem szeregu dzieł i artykułów, których opracowania podjął się Muhammad Amara w Al-Amal al-kamila li-Rifa at-Tahtawi (Dzieła zebrane At-Tahtawiego) wydanych w Bejrucie 1973 roku przez wydawnictwo Al-Mu'assasa al-Arabijja li-ad-Dirasat wa-an-Naszr, a punkt wyjścia do sformułowanej przez niego koncepcji reformy władzy i społeczeństwa stanowi Kitab tachlis al-ibriz fi talchis Bariz (Wydobycie czystego złota czyli krótki opis Paryża). Tunezyjczyk natomiast swoje koncepcję zreformowania świata muzułmańskiego wyłożył w dziele Akwam al-masalik fi marifat ahwal al-mamalik (Najprostsza droga do poznania sytuacji w królestwach) wydanym w postaci zeszytów w okresie sty- 
czeń-sierpień 1868 roku oraz trzykrotnie w całości: w 1990, 2000 i 2004 roku, nakładem wydawnictwa Ministerstwa Kultury Al-Mudżamma at-Tunusi li-al-Ulum wa-al-Adab wa-al-Funun „Bajt al-Hikma”, z analizą tekstu i komentarzem Mansafa asz-Szanufiego.

\section{Wzory europejskie a muzułmańska tradycja polityczna na podstawie Kitab tachlis al-ibrizfi talchis Bariz (Wydobycie czystego złota, czyli krótki opis Paryża) Rifa'y at-Tahtawiego}

W dziele Kitab tachlis al-ibriz fi talchis Bariz, które do 1850 roku stanowiło jedyny szczegółowy opis kraju europejskiego w języku arabskim, a do I wojny światowej obowiązkową lekturę wszystkich urzędników egipskich, At-Tahtawi zawarł opis instytucji politycznych, społecznych, kulturalnych, edukacyjnych, z jakimi zetknął się w Paryżu, a które uważał za wzorcowe i godne przeniesienia na rodzimy grunt, powołując się na hadis: „Wiedzy szukajcie wszędzie choćby w Chinach”, całości zaś przyświecało arabskie motto: „Pierwszeństwo przysługuje temu, kto idzie przodem”.

Książkę, złożoną z sześciu obszernych rozdziałów, otwiera Mukaddima (Wstęp), w której autor, po wyjaśnieniu powodów wyjazdu do Francji oraz potwierdzeniu konieczności zdobywania wiedzy oraz obeznania z nauką, sztuką, rzemiosłem i produkcją, przedstawia charakterystykę tego kraju na tle innych państw europejskich oraz cechy wyróżniające jego mieszkańców, które legły u podstaw wyboru Francji jako kraju docelowego dla szukających dobrego wykształcenia i właściwych wzorców cywilizacyjnych stypendystów egipskich. Jak głosi tytul jednego z podrozdziałów Wstępu, w dziele będzie mowa „o sprawach niezwykłych, które było nam dane poznać podczas podróży i pobytu w tym mieście pełnym nauki, sztuki i sprawiedliwości”.

Pierwsze trzy rozdziały, których At-Tahtawi nie opatrzył tytułami, poświęcone są kolejno: Aleksandrii, Marsylii i Paryżowi, przy czym ten ostatni, podzielony na trzynaście części, zawiera także szczegółowy opis Francji, począwszy od położenia geograficznego, bogactw naturalnych oraz charakterystyki regionu i kraju, przez prezentację zagadnień o charakterze społecznym i socjalnym (warunki zamieszkania i poziom życia, sposoby ubioru i spędzania wolnego czasu, tradycje żywieniowe, sytuacja wyznaniowa, opieka zdrowotna i szczególne zainteresowanie okazywane naukom medycznym, instytucje dobroczynne, postęp i osiągnięcia w zakresie nauki i sztuki), po zagadnienia administracji państwowej, w tym przysługujące Francuzom prawa, sposoby sprawowania władzy sądowniczej, prawodawczej i wykonawczej oraz udział społeczeństwa w rządach.

W czwartym rozdziale, podzielonym na sześć części i zatytułowanym Fima kunna alajhi min-al-idżtihad (Wysiłek, który musieliśmy podjąć) reformator pochyla się nad sytuacją egipskich studentów podejmujących naukę w Paryżu i problemami, z którymi borykali się 
podczas pobytu za granicą, a następnie prezentuje swoją korespondencję z przedstawicielami francuskiego świata nauki i dzieła, z jakimi dane mu było zapoznać się w trakcie misji.

W rozdziale piątym, Fi zikr ma waka'a min-al-fitna fi Faransa wa-azl al-malik kabla rudżu'ina ila Misr (Opowieść o zamieszkach we Francji i detronizacji króla, do których doszło przed naszym powrotem do Egiptu), na który składa się siedem podrozdziałów, sięga do sytuacji Francji: wybuchu rewolucji lipcowej 1830 roku, obalenia Karola X i osadzenia na tronie Ludwika Filipa I oraz zmian społeczno-politycznych, jakie były wynikiem tych wydarzeń.

Rozdział szósty, Fi dikr nubdat min al-ulum wa-al-funun al-masruda fi al-bab as-sani min al-mukaddima (Opowieść o naukach i sztukach, której fragmenty zamieszczone były w podrozdziale drugim Wstępu) podzielony na siedem części, poświęca w całości nauce i sztuce, począwszy od dokonanej przez Europejczyków klasyfikacji tych dziedzin, w tym klasyfikacji genetycznej języków, po opis literatury, retoryki, logiki, filozofii i arytmetyki. Zwieńczeniem rozważań wokół zagadnień francuskiego życia kulturalnego, społecznego i politycznego jest Al-Chatima (Zakończenie), zatytułowane Fi rudżu'ina min Bariz ila Misr wa fi iddat umur muchtalifa (O naszym powrocie z Paryża do Egiptu i różnych innych kwestiach), które stanowi próbę podsumowania obserwacji i przemyśleń autora, porównania Francji reprezentującej Zachód z Egiptem jako jednym z krajów świata muzułmańskiego, wreszcie - wskazania konieczności pójścia śladem Europy, co umożliwi rozwój cywilizacyjny tegoż świata zgodnie z arabskim mottem: „Pierwszeństwo przysługuje temu, kto idzie przodem”.

Szczególne znaczenie miał zamieszczony w dziele opis administracji państwa i instytucji politycznych oraz zakres praw przysługujących społeczeństwu. Egipski reformator wyjaśnił tam pojęcia związane $\mathrm{z}$ francuskimi wzorcami sprawowania władzy, dokonał przekładu konstytucji francuskiej z 1830 roku i wyrazil podziw dla tego aktu, wskazując, że Francuzi przez wprowadzenie w życie zasad konstytucyjnych osiągnęli „rozkwit swojego kraju, rozwój dziedzin wiedzy, kumulację bogactw i spokój serc. Wybrali postępowanie racjonalne, zgodne z zasadami sprawiedliwości ( $a d l)$ i praworządności (insaf), tak więc znika niesprawiedliwość, a sprawiedliwość staje się podstawą rozwoju cywilizacyjnego (umran)"11. Podkreślił, że król Francji nie posiadał władzy absolutnej, ponieważ była ona ograniczona prawem: podczas gdy mianowana przez niego Izba Parów (Izba Wyższa) reprezentowała interesy monarchy, pochodząca z wyborów Izba Deputowanych (Izba Niższa) reprezentowała ludność kraju i w związku z tym sprawowała kontrolę nad ustawodawstwem, polityką władz, dochodami i wydatkami państwa. Przytoczył postanowienia dokumentu broniące Francuzów, ich wolności i równości (równość wobec prawa i obejmowania funkcji państwowych, wolność słowa, wyznania, przekonań, prawo do ochrony własności itd.), a z drugiej - utrwalające prerogatywy władcy - jego centralną pozycję w państwie czy prawo do inicjatywy ustawodawczej.

Wiele uwagi (rozdział piąty Kitab..., Fi dikr ma waka'a min-al-fitna fi Faransa wa-azl al-malik kabla rudżu'ina ila Misr) poświęca at-Tahtawi francuskim wydarzeniom politycznym z okresu tuż przed swoim powrotem do Egiptu, tzw. „rewolucji licowej” (27-29 lipca 1830), która udaremniła próbę powrotu do absolutyzmu dokonaną przez Karola X (1824-1830) poprzez obalenie go i przekazanie władzy monarszej Ludwikowi Filipowi (1830-1848). Wskazując, że wydarzenia te „należały do czasów pozytywnie wspominanych przez Francu-

11 Rifa at-Tahtawi, Kitab tachlis al-ibriz fi talchis Bariz, [w:] M. Amara, Al-Amal al-kamila li-Rifa at-Tahtawi, Bajrut 1973, s. 95. 
zów"12, wyjaśnia ich genezę: wykrystalizowanie się w kraju dwóch orientacji: rojalistycznej, której zwolennicy, wywodzący się przeważnie ze środowisk klerykalnych, opowiadali się za oddaniem spraw w ręce władcy bez kwestionowania zakresu jego uprawnień, a co za tym idzie za monarchią absolutną oraz liberalnej, skupiającej obok większości obywateli szereg filozofów, uczonych i mędrców, optujących na rzecz stosowania prawa i ograniczenia władcy absolutnej króla, wprowadzenia monarchii konstytucyjnej lub republiki. „Monarchii lipcowa" jako okres przekształceń we wszystkich zasadniczych dziedzinach życia społecznego - formowania się parlamentaryzmu i współczesnych partii politycznych, rozwoju nowoczesnego kapitalizmu i zmian w gospodarce, jak i przemian kulturalnych (romantyzm) oraz wydana przez Ludwika XVIII Karta Konstytucyjna (przełożona w dziele na język arabski) były dla At-Tahtawiego potwierdzeniem praw i obowiązków obywateli Francji.

Podziw dla francuskich dokonań i koncepcji w zakresie władzy, społeczeństwa, systemów politycznych, prawnych i społecznych legł u podstaw dążenia do połączenia ich z muzułmańską teorią polityczną poprzez dowiedzenie, że społeczno-polityczna myśl islamu zawsze głosiła idee stanowiące trzon europejskiej myśli oświeceniowej, jak choćby prawo jednostki do życia w wolności i korzystania z niej w wolnym społeczeństwie oraz oparcie idealnego społeczeństwa na sprawiedliwości i wolności:

Ktokolwiek miał do czynienia z nauką o podstawach muzułmańskiej jurysprudencji (ilm usul al-fikh), musiał z pewnością dojść do tych samych racjonalnych wniosków, jakie stały się udziałem wybitnych umysłów pozostałych narodów cywilizowanych (mutamaddin), czyniąc z nich podstawę ustawodawstwa tworzącego podwaliny ich rozwoju cywilizacyjnego (umran) i politycznego - $\mathrm{i}$ to rzadko wykracza poza podstawowe reguły gałęzi prawodawstwa muzułmańskiego (furu al-fikh). To, co u nas nazywamy podstawami prawodawstwa, oni nazywają czymś w rodzaju praw naturalnych lub praktyk atawistycznych (nawamis fitrijja). Są one regułami rozumowymi, na których narody te budują swoje cywilne instytucje. To, co my nazywamy gałęziami prawodawstwa, oni nazywają prawami lub zasadami cywilnymi, a to, co my nazywamy sprawiedliwością czy właściwym postępowaniem (ihsan), oni nazywają wolnością i równością. ${ }^{13}$

Zdaniem At-Tahtawiego, postulaty unowocześnienia państwa i społeczeństwa oraz uznania takich pojęć, jak: demokracja, wolność, równość, sprawiedliwość, prawa obywatelskie nie stanowią odejścia od tradycji i zasad islamu, były bowiem w nich obecne, choć pod innymi nazwami.

Mając na uwadze to, że naród winien być źródłem wszelkiej władzy, a osoba stojąca na czele systemu politycznego winna bronić prawa i mu podlegać, At-Tahtawi przedstawia szczegółowo francuską praktykę parlamentarno-demokratyczną: tryb przeprowadzania wyborów, system okręgów wyborczych z ich liczbą, warunkami kandydowania i głosowania, długość kadencji posłów, a także informacje na temat immunitetu parlamentarnego, jawnych i tajnych posiedzeń, komisji parlamentarnych, relacji między członkami rządu a parlamentem, kompetencji tego ostatniego w zakresie rozliczania ministrów. Przedstawienie poznanych we Francji praktyk politycznych i wizerunku zachodniej cywilizacji jest celowym posunięciem myśliciela i jednym z elementów jego koncepcji reformatorskiej prowadzącym do kolejnego punktu - adaptowania obcych wzorów do świata arabsko-mu-

\footnotetext{
12 Ibidem, s. 199

13 Ibidem, s. 469.
} 
zułmańskiego bez naruszenia tradycyjnego systemu wartości i norm, co ma stanowić podstawę do unowocześnienia tego świata.

W kręgu zainteresowań reformatora znalazła się także kwestia wolności czy swobód obywatelskich określanych przez niego terminem hurrijjat amma (swobody powszechne) bądź hukuk madanijja (prawa cywilne), będących podstawowym warunkiem rozwoju (umran). Zawierają one - w ujęciu At-Tahtawiego - dwa elementy: równość (taswija) i wolność (hurrijja), a każdy z nich stanowi naturalne i niezbywalne prawo jednostki. Pierwsze z nich oznacza równość wszystkich obywateli w obliczu prawa i brak jakichkolwiek różnic oprócz stopnia poszanowania dla prawa i działania zgodnie $\mathrm{z}$ jego postanowieniami: „Każdy człowiek dysponuje swoimi majątkami czy prawami tak jak to czynią inni”"14. Drugie - obok prywatnej sfery życia jednostki - obejmuje także swobody polityczne, religijne, wolność wypowiedzi i własności. Jak mówi: „Wolność stanowi zasadniczą drogę ku szczęśliwości ludności państw. Wolność, która jest przypieczętowana w sercu człowieka od zarania jest źródłem jego godności. Przynosi korzyść ojczyźnie, obywatelom i przywódcy państwa"15. Reforma ustroju i społeczeństwa wolnych obywateli ma prowadzić do stanu pełnego rozwoju cywilizacyjnego (tamaddun), opartego na dwóch podstawach: moralnejczyli związanej z rozwojem moralnym, a zatem z religią i prawodawstwem religijnym, oraz materialnej - czyli dotyczącej osiągnięcia postępu w dziedzinach użytecznych publicznie, tj. w rolnictwie, handlu, przemyśle ${ }^{16}$.

Co ciekawe, mimo że At-Tahtawi reprezentował środowiska religijne, to kryterium rozwoju, a nie religijności, zajmuje w jego myśli społeczno-politycznej miejsce pierwszoplanowe. Metoda poszukiwań tego myśliciela w zakresie teorii władzy i społeczeństwa charakteryzuje się racjonalizmem, według niego bowiem to rozum ma stanowić podstawę działań państwa i społeczeństwa egipskiego. Dokonując analizy teorii i praktyki rządzenia we Francji i Egipcie wskazuje na zasadniczą różnicę pomiędzy ich uzasadnieniem, które w Europie Zachodniej ma charakter racjonalny, a w świecie arabsko-muzułmańskim - teologiczny. Mając na uwadze tę przepaść, wzywał rodaków do stosowania racjonalnej miary tahsin wa-at-takbih (wybór pomiędzy lepszym a gorszym).

Reformator zdecydowanie przeciwstawiał się nieograniczonej władzy despotycznej, na czele władzy państwowej - zgodnie z jego myślą - miał stać absolutny władca o uprawnieniach wykonawczych, ograniczonych potrzebą poszanowania prawa i szacunku wobec ludzi stojących na jego straży. Był zwolennikiem ograniczonej ustawowo władzy królewskiej, nie zaś osmańskiego sułtana, jednocześnie popierał i pochwalał rządy Muhammada Alego, dążącego do uniezależnienia Egiptu od Wysokiej Porty. W odniesieniu do samej władzy wysuwał przykład francuskiej monarchii konstytucyjnej, starał się jednak łagodzić ostrze doktryny skierowanej przeciwko panującym despotom, a przede wszystkim - osadzić ją w tradycji muzułmańskiej. Odrzucając pogląd, że islam nadaje rządzącym pełnię władzy i wolności, podkreślał zgodność z duchem islamu nowoczesnych konstytucji ograniczających kompetencje rządów, gdyż zasada nadrzędności prawa odpowiada podstawowemu principium rządów muzułmańskich: podporządkowaniu się władcy regułom szariatu.

\footnotetext{
14 Ibidem, s. 477.

15 Ibidem, s. 475

${ }^{16}$ Kwestie te omawia szeroko w kolejnym dziele: Manahidż al-albab al-misrijja fi mabahidż al-adab al-asrijja (Źródła umysłów egipskich. O radości płynącej ze współczesnego wychowania), [w:] M. Amara, Al-Amal al-kamila li-Rifa at-Tahtawi, Bajrut 1973.
} 


\section{Wzory europejskie a muzułmańska tradycja polityczna na podstawie Akwam al-masalik fi marifat ahwal al-mamalik Chajr ad-Dina at-Tunusiego}

Tunezyjski reformator rozważa w swoim dziele przyczyny zacofania i upadku świata arabsko-muzułmańskiego oraz konieczność dokonania zmian z wykorzystaniem doświadczeń innych, w szczególności Zachodu, poprzez poznanie metod, które doprowadziły Europejczyków do obecnej potęgi i przejęcia tego, co jest przydatne w świecie arabskim i muzułmańskim, bez odrzucania własnych wartości. Punktem wyjścia do unowocześnienia struktur i instytucji politycznych, społecznych i gospodarczych miało być spotkanie cywilizacyjne pomiędzy kulturą Zachodu a kulturą islamu.

At-Tunusi rozpoczął swoje dzieło - złożone z trzech rozdziałów: Prolegomena (Al-Mukaddima), Historia (At-Tarich) i Recenzje (Takariz) - Przedmowa (Chutbat al-kitab), w której informuje czytelnika, że Najprostsza droga do poznania sytuacji $w$ królestwach zawiera kwintesencję jego wiedzy i résumé jego poglądów dotyczących narodzin i schyłku państw, przyczyn ich rozwoju i upadku. Jest rezultatem długich rozważań dotyczących tych państw, zarówno ich narodzin, jak i końca:

Zaprawdę, po długich rozważaniach przyczyn rozwoju społeczeństw i ich zacofania, pokolenie po pokoleniu - w oparciu o dostępne mi źródła poruszające zagadnienia historii muzułmańskiej i europejskiej, które wyszły spod pióra twórców obu stron, z uwzględnieniem tego, jaka była i do czego doszła umma muzułmańska i dokąd na podstawie przewidywań wynikających z doświadczeń zaprowadzi ją to w przyszłości ${ }^{17}$.

Poprzez swoje dzieło reformator podejmował próbę ostrzeżenia muzułmanów przed losem, jaki może ich spotkać oraz do wskazania środków, które umożliwią im wyjście z zacofania ku odrodzeniu, a mianowicie - konieczności przejęcia od Zachodu jego wiedzy i wkroczeniu dzięki temu na drogę rozwoju, przy jednoczesnym poszanowaniu litery prawa muzułmańskiego. Nie widział w tym żadnej sprzeczności, bowiem muzułmanie muszą dokonać wyboru zgodnego z tekstami prawa muzułmańskiego „środków, które doprowadziły państwa europejskie do obecnej siły i władzy”. Warunkiem tego jest, zgodnie ze słowami At-Tunusiego „dokonanie wyboru tego, co jest odpowiednie dla naszej sytuacji i zgodne $\mathrm{z}$ literą prawa muzułmańskiego"18.

Myśliciel rozpoczyna Prolegomena od przedstawienia przyczyn, które pchnęly go do napisania dzieła, a które sprowadzić można do dwóch kwestii: z jednej strony celem Najprostszej drogi... ma być pobudzenie tych, którzy zajmują się sprawami państwa i społeczeństwa, tj. „ludzi polityki i nauki” (ridżal as-sijasa wa-al-ilm) oraz zachęcenie ich do skierowania

\footnotetext{
17 Chajr ad-Din at-Tunusi, Akwam al-masalik fi marifat ahwal al-mamalik, Tunus 2004, s. 93-94.

18 Ibidem, s. 97.
} 
się w stronę cywilizacji zachodniej i przejęcia środków, które spowodowały jej siłę i potęgę, a z drugiej strony - zadaniem jej jest powstrzymanie tych, którzy uważają, że przejawy i elementy cywilizacji zachodniej są sprzeczne z prawem muzułmańskim, tj. „ludzi religii” (ridżal ad-din), których opinie należy odrzucić i puścić w zapomnienie, ponieważ stanowią przeszkodę na drodze postępu i rozwoju.

Na treść Prolegomen składa się szereg postulatów sformułowanych przez Chajr ad-Dina. Przede wszystkim konieczność naśladowania Zachodu, dlatego porusza tu zagadnienie zgody na adaptację przez muzułmanów nauki i wiedzy oraz wszystkiego, co określa mianem „uczynków uważanych za dobre” (al-afal al-mustahsina) pochodzących od innych, nawet, jeśli nie są muzułmanami, i przekonuje, że zapożyczanie od cywilizacji zachodniej nie musi być uważane za niewłaściwe, ponieważ należy do kategorii al-afal al-mustahsina, pod warunkiem, że prowadzi do odrodzenia muzułmanów. Następnie konieczność zlikwidowania władzy absolutnej, tu At-Tunusi udowadnia, że absolutyzm polityczny prowadzi do dezintegracji państw i rujnowania społeczeństw. Wreszcie konieczność ustanowienia instytucji politycznych, stąd przedstawienie zachodniej koncepcji demokracji z oparcim jej na muzulmańskiej radzie konsultacyjnej. A także szereg innych postulatów, poprzez które At-Tunusi próbował rozwiązać problemy społeczeństwa i państwa arabsko-muzułmańskiego.

Po wyłożeniu swoich idei reformatorskich przechodzi on do Historii, która stanowi drugi rozdział książki. Opisuje tam kilkanaście państw europejskich, ich systemów politycznych, administracyjnych i gospodarczych, a także innych, związanych z odrodzeniem społeczeństw i ich rozwojem. At-Tunusi wstępuje tu w roli lekarza, którego zadaniem jest postawienie diagnozy poprzez rozpoznanie choroby - choroby muzułmanów, jaka toczy ich życie społeczne, gospodarcze i polityczne, zgodnie z opisem, który umieścił w Prolegomenach - i przepisanie leku - leku europejskiego, który stanowi panaceum na bolączki świata arabsko-muzułmańskiego, na podstawie tego, co przedstawił w Historii. Poprzez przegląd sytuacji Europy At-Tunusi podejmuje próbę uwidocznienia muzułmanom, że wyjście z upadku, a co za tym idzie ich odrodzenie, może być urzeczywistnione jedynie poprzez pójście śladem państw europejskich, co w jego rozumieniu oznacza akceptację wiedzy i nowoczesnych nauk Zachodu. Niezbędnym zaś tego warunkiem jest ukształtowanie świadomości, że nie wszystko, co pochodzi od Europy jest zakazane, niedozwolone, niezgodne $\mathrm{z}$ prawem islamu, jak z uporem twierdziły środowiska religijne, a także uświadomienie sobie, że jedna epoka odeszła, a nastąpiła kolejna, mówiąc innymi słowy - muzułmanie winni pogodzić się z faktem, że utracili pozycję, którą mieli w czasach średniowiecza, a której podstawą był islam jako źródło wiedzy i nauki, zmieniły się bowiem uwarunkowania, a wraz z nimi zmieniły się społeczeństwa i narody. Podkreśla, że przystąpienie do tej rywalizacji i dotarcie do celu możliwe jest tylko poprzez adaptowanie i przyjęcie osiągnięć Europy w zakresie cywilizacji i postępu, a mówiąc językiem At-Tunusiego „poprzez poznanie sytuacji innych, tych, którzy nie należą do naszej grupy”.

Zgodnie z koncepcją Tunezyjczyka, warunek konieczny do osiągnięcia celu, jakim jest odrodzenie, stanowi zapoznanie się z „sytuacją innych”, tj. z sytuacją Europy, która jako jedyna posiada obecnie środki prowadzące na drogę postępu i rozwoju, przy czym owo pozyskanie wiedzy winno nastąpić po przeanalizowaniu planu, tak, by umożliwić odróżnienie tego, co odpowiednie i właściwe dla muzułmanów, od tego, co pozostaje w sprzeczności z obyczajami i tożsamością muzułmańską. Przyjęcie nowoczesnej europejskiej wiedzy bądź tego, co At-Tunusi nazywa „przyczynami europejskiego postępu”, ma przebiegać dzięki „zasadom 
konstruktywnej budowy", tak żeby było zgodne z wymogami epoki z jednej strony i z wymogami prawa muzułmańskiego $\mathrm{z}$ drugiej. Istotnym elementem tejże koncepcji jest więc fakt, że reformator nie kieruje się w stronę europejskiej cywilizacji odarty ze swoich korzeni, lecz analizuje ją jako muzułmanin, a punktem wyjścia do tej analizy jest przekonanie i świadomość własnej odrębności i tożsamości, a przede wszystkim podporządkowanie prawu religijnemu, z którym „przyczyny europejskiego postępu”, których przejęcie postuluje, nie mogą pozostawać w sprzeczności. W ten sposób At-Tunusi staje w opozycji do opinii panującej w XIX wieku, a mianowicie, że wszelkie przejawy i elementy cywilizacji zachodniej nie są uznawane przez prawo muzułmańskie ani akceptowane przez religię, stąd należy sprzeciwiać się wszystkiemu, czego wymagało otwarcie na cywilizację Europy i jej kulturę.

Zdaniem reformatora, na skutek błędnego spojrzenia na nowoczesną cywilizację, w którym zasadniczą rolę odgrywali ulama (alimowie), muzułmanie trwali w zacofaniu, podczas gdy społeczeństwa chrześcijańskie, dzięki zachodniej cywilizacji, pokonały ogromny dystans w swym rozwoju. Jak mówi:

Niestety, to spojrzenie na cywilizację zachodnią ma nadal ogromny wpływ na część środowisk w społeczeństwach muzułmańskich, nawet, jeśli niektóre ich grupy nie zgadzają się na słuchanie ich apelów, jak przestrzeganie przed edukacją kobiet i przejmowaniem nowoczesnego ustawodawstwa [...] To są przyczyny, które sprawiają, że jeśli nawet chrześcijanie i muzułmanie spotkaliby się w jednym kraju, to chrześcijanie ubiegliby ich w adaptacji cywilizacji zachodniej i korzystaniu z niej. Niektórzy ludzie przypisują to naturze islamu, a przecież islam nie zakazuje adaptowania tego, co przynosi korzyść, niezależnie skąd i od kogo pochodzi ${ }^{19}$.

At-Tunusi podjał trudne dzieło krytykowania owych opinii i zdecydowanej reakcji na stanowiska przeciwne unowocześnianiu i reformie Tunezji, przede wszystkim przez udowadnianie, że nie ma kontrastu pomiędzy koncepcjami europejskimi a tymi, które funkcjonują w społeczeństwie arabsko-muzułmańskim. Przytaczał argumenty na to, że prawo muzułmańskie nie może być sprzeczne z rozwojem i postępem, przeciwnie - zachęca do nich i uważa je za ucieleśnienie koncepcji muzułmańskiego dżihadu, ten bowiem nie oznacza jedynie głoszenia wiary mieczem, lecz także nieprzerwaną walkę mającą na celu potęgę muzułmanów, ich rozwój i postęp cywilizacyjny. Dlatego przystąpił do formułowania programu reform opartego na ożywieniu wartości muzułmańskich takich, jak: szura (konsultowanie), hurrijja (wolność) i adl (sprawiedliwość), które prowadzić miały do odrzucenia systemu despotycznego, przyczyny upadku ummy. Ów teoretyczny wykład, ujęty w Najprostszej drodze... miał więc jeden konkretny cel, a mianowicie - uzyskanie poparcia dla postulowanych reform, od którego zależał sukces programu politycznego, a co za tym idzie - poprawa sytuacji wewnętrznej i zewnętrznej Tunezji, a w szerszym zakresie - poprawa sytuacji wewnętrznej i zewnętrznej świata muzułmańskiego. Niezbędnym warunkiem wprowadzenia zmian miało być poparcie dwóch wrogich At-Tuniseimu ugrupowań, z jednej strony mocarstw europejskich, zwłaszcza Francji, Włoch i Wielkiej Brytanii, które stanowiły zagrożenie dla niezależności i integralności Tunezji, a z drugiej - uczonych muzułmańskich, którzy działając w porozumieniu z elitami politycznymi tworzyli integralną część systemu absolutnego.

${ }^{19}$ Cytat za: A. Amin, Zu'ama al-islah fi al-asr al-hadis..., s. 160. 


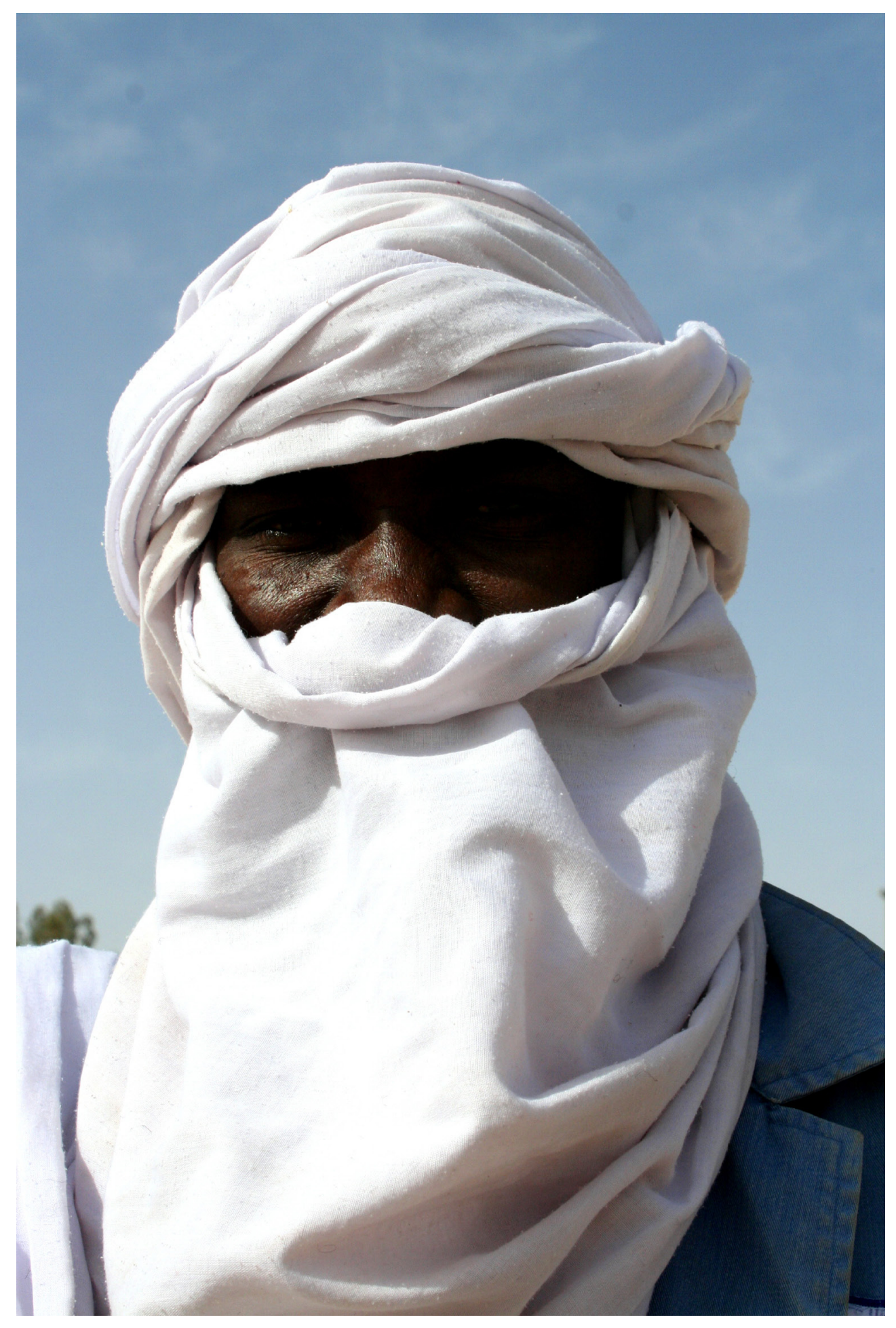

Taureg w białym zawoju,

Południowa Libia

(fot. Z. Preisner) 


\section{Konieczność naśladowania Zachodu (al-iktibas min al-Gharb)}

Rifa at-Tahtawi i Chajr ad-Din at-Tunusi nie odrzucali obranych przez myślicieli epoki odrodzenia w XIX wieku podstaw, przyjętych dla stosunków między cywilizacją muzulmańską a europejską, opartych na swoistym kompromisie łączącym koncepcje Zachodu z ideami odziedziczonymi przez społeczeństwo arabsko-muzułmańskie, tak, że jedne nie były sprzeczne z drugimi. Ów kompromis nie zawsze był łatwy i możliwy do spełnienia, ponieważ rozwiązania zachodnie trafiały na zupełnie obcy grunt świata arabsko-muzułmańskiego, czego przykładem jest próba pogodzenia muzułmańskiej szury z koncepcją zachodniej demokracji czy ahl al-hall wa-al-akd z ideą reprezentantów narodu. Obaj reformatorzy - podobnie jak inni myśliciele z XIX wieku - dążyli do wypracowania owych kompromisowych rozwiązań, tj. pogodzenia „środków, które doprowadzily państwa europejskie do obecnej siły i władzy” z „literą prawa muzułmańskiego”. Byli w pełni przekonani, że przyczyną obecnej siły i dobrej sytuacji politycznej, społecznej i gospodarczej Europy są jej rozwiązania polityczne, których podstawowymi cechami są sprawiedliwość (adl) i wolność (hurrijja): „Przyczyną tego, o czym wspomnieliśmy, jest postęp europejskiej wiedzy wynikającej z instytucji politycznych opartych na sprawiedliwości i wolności”20. Im przypisują istotne znaczenie w rozwoju nauki, sztuki i gospodarki: „I osiągnęli te cele oraz postęp w nauce i produkcji dzięki instytucjom opartym na sprawiedliwości politycznej, a także dzięki działalności gospodarczej, eksploatacji skarbów ziemi oraz znajomości rolnictwa i handlu. Podstawą tego były bezpieczeństwo i sprawiedliwość, które stały się naturalne w tych kraja$\mathrm{ch}^{\text {”21. }}$. Elementem niezbędnym dla rozwoju jest więc bezpieczeństwo, będące bezpośrednią pochodną sprawiedliwych rządów: „Podstawą tego wszystkiego jest właściwe rządzenie oparte na bezpieczeństwie, a to przynosi nadzieję, doskonałość w pracy, co widać w państwach europejskich tak jasno, że niepotrzebne są wyjaśnienia”22.

Przedstawienie przyczyn supremacji europejskiej, a następnie wizerunku zachodniej cywilizacji jest celem autorów Akwam al-masalik fi marifat al-mamalik i Kitab tachlis al-ibriz fi talchis Bariz oraz jednym z elementów ich koncepcji reformatorskiej prowadzącym do kolejnego punktu - adaptowania obcych wzorów do świata arabsko-muzułmańskiego. Adaptowania ich bez naruszenia tradycyjnego systemu wartości i norm, co ma stanowić podstawę do unowocześnienia tego świata, przystosowania go do nowych okoliczności i wyjścia $\mathrm{z}$ upadku w kierunku rozwoju i postępu we wszystkich dziedzinach życia. Skoncentrowali się na istotnej kwestii, a mianowicie konieczności naśladowania Zachodu (al-iktibas min al-Gharb), znajdującego się na szczycie drabiny rozwoju cywilizacyjnego, jak to jest widziane przez świat arabsko-muzułmański, który znalazł się z kolei na jej dole, oraz na zagadnieniu, wynikającym z tejże kwestii, tj. legitymizacji owego naśladowania i potwierdzeniu go prawem muzulmańskim. Ich koncepcje zdominował problem reform wewnętrznych i ożywienia wartości muzułmańskich, takich jak konsultacja (szura), wolność (hurrijja) i sprawiedliwość (adl) oraz systemu władzy, który przekształcił się w despotyczną władzę absolutną

\footnotetext{
${ }^{20}$ Chajr ad-Din at-Tunusi, op. cit., s. 105.

21 Ibidem.

22 Ibidem.
} 
(hukm mutlak istibdadi), a to doprowadziło świat arabsko-muzułmański do kryzysu i upadku. Swoje postulaty kierowali przede wszystkim do przywódców narodów arabsko-muzułmańskich, a zwłaszcza do „ludzi religii” (ridżal ad-din), którzy wraz z „ludźmi polityki” (ridżal as-sijasa) uczestniczyli w ustanawianiu władzy absolutnej, a także do Europy podważającej gotowość świata arabsko-muzułmańskiego do przeprowadzenia reform i odrodzenia. Dzieło At-Tunusiego miało być odpowiedzią na wątpliwości Zachodu i argumentem potwierdzającym przygotowanie i zdecydowanie Arabów na wejście na drogę postępu, stąd troska autora o przekłady Najprostszej drogi... na język francuski i angielski²3.

Koncepcje At-Tahtawiego i At-Tunusiego dotyczące funkcjonowania państwa nie były czymś nowym, łatwo bowiem w nich znaleźć szereg odniesień do idei XVIII-wiecznych europejskich myślicieli politycznych, a przede wszystkim Monteskiusza i jego teorii o organizacji państwa odwołującej się do podziału władzy oraz wolności jednostki, której rzeczywistym odbiciem była współczesna reformatorowi Europa. Istotną cechą ich myśli politycznej jest przyjęcie zasady podziału władzy na wykonawczą, sądowniczą i prawodawczą, domaganie się, żeby powyższa zasada legła u podstaw systemu sprawowania władzy. Nowatorstwo autorów zawiera się natomiast w metodzie, na podstawie której dokonali próby zidentyfikowania zapożyczonych idei z tradycyjną arabsko-muzułmańską teorią i praktyką polityczną oraz dostosowania ich do warunków i wymogów epoki. W prosty sposób starali się przenieść na grunt muzulmański koncepcję rządów prawa w społeczeństwie przypisując tę rolę szariatowi, byli bowiem przekonani, że prawo muzułmańskie, odpowiednio zinterpretowane i zastosowane w odniesieniu do zmieniającej się rzeczywistości, jest w stanie sprostać współczesnym wymaganiom. Celem pogodzenia tradycji ze współczesną europejską myślą polityczną i jej elementami w postaci systemu kontroli i podziału władzy dokonali swoistej reinterpretacji muzułmańskiej teorii politycznej, przede wszystkim w materii dotyczącej kalifatu, co pozwoliło na uzasadnienie koncepcji konsultacji i przedstawicielstwa (szura), sprawiedliwości (adl) i wolności (hurrijja).

Dzieła At-Tahtawiego i At-Tunusiego przyczyniły się znacząco do przygotowania umysłów i rozpowszechnienia idei nowoczesnego państwa i społeczeństwa egipskiego i tunezyjskiego, odnosiły się także do innych krajów arabskich i muzułmańskich. Odnowa ich instytucji politycznych, społecznych, gospodarczych i edukacyjnych, którą postulowali w swych dziełach i działalności, celem wyrwania się z zacofania odziedziczonego po Osmanach i Mamelukach, dokonać się mogła jedynie za pomocną nowoczesnej nauki i wiedzy, a co za tym idzie - otwarciu Orientu na zdobycze zachodniej kultury i cywilizacji. To przekonanie stanowiło punkt wyjścia do rozważań różnych aspektów problematyki reformy władzy i społeczeństwa, posłużyło stworzeniu zrębów własnej doktryny w imię dokonania transformacji politycznej, społecznej i kulturalnej, mającej na celu rozwój zdolności i potencjału ummy oraz odzyskania należnego światu arabsko-muzułmańskiemu miejsca na arenie międzynarodowej. Znaczenie sformułowanego przez nich programu reformatorskiego i całokształtu myśli politycznej sprawiło, że Rifa at-Tahtawi zyskał miano „prekursora europejskiego modernizmu” i „pioniera odnowy w świecie arabsko-muzułmańskim”, a Chajr ad-Dina at-Tunusiego uznano za „ojca tunezyjskiego odrodzenia", ich dzieła zaś, Akwam al-masalik fi marifat ahwal al-mamalik i Kitab tachlis al-ibriz fi talchis Bariz - uważane są za jedne z najwybitniejszych XIX-wiecznych dzieł arabskich w zakresie myśli społeczno-politycznej.

${ }_{23}$ Przekład francuski Réformes nécessaires aux états musulmans ukazał się w Paryżu w 1868 roku, a tłumaczenie angielskie Necessary Reforms of the musulman states. Essay which forms the first part of the political and statistical work entitled "The surest way to know the state of the nations" zostało wydane w Atenach w 1874. 